protein of these cells themselves, yielding a filtrate from which, as we have found by experiment, oxyhemoglobin more readily crystallizes and in a much purer state than by any other known method.

[From the Robert Hare Chemical Laboratory, University of Penna.]

\title{
THE PRECIPITATION OF ENZYMES FROM THEIR SOLUTIONS BY MOIST ALUMINIUM HYDROXIDE.
}

BY WX, H. WELKer AND JOHN MARshall.

Received April 14, 1913.

These experiments were undertaken to determin whether or not solutions of enzymes when treated with aluminium hydroxide jelly and filtered would retain their enzyme activity. The aluminium hydroxide was prepared as described by us in a previous paper. ${ }^{1}$ Equal volumes of enzyme solution and the reagent were shaken vigorously in a test tube for a few seconds and then filtered. Appropriate tests were made on the filtrates to determin enzyme action.

\section{Enzyme Solutions Employed:}

Peroxydase (water extract of potato $\ldots \ldots \ldots \ldots \ldots$. . Precipitated.

Oxydase (water extract of potato) ................ Precipitated.

Amylase (saliva) . . . . . . . . . . . . . . . . . Incompletely precipitated.

Pepsin (water solution of commercial pepsin) ......... Precipitated.

Pepsin $(0.2 \% \mathrm{HCl}$ solution of commerical pepsin) ........ Precipitated.

Rennin (water solution of commercial rennin) ......... Precipitated.

Trypsin (water solution of commercial trypsin)......... Precipitated.

Trypsin $\left(0.5 \% \mathrm{Na}_{2} \mathrm{CO}_{3}\right.$ solution of commercial trypsin)... . Precipitated.

Trypsin ( $30 \%$ alcohol extract of pancreas)............ Precipitated.

Trypsin $(30 \%$ alcohol extract of pancreas + equal vol. $1 \%$

$\mathrm{Na}_{2} \mathrm{CO}_{3}$ sol. $) \ldots \ldots \ldots \ldots \ldots \ldots \ldots \ldots \ldots \ldots \ldots \ldots . \ldots \ldots$ Precipitated.

Amylase $(30 \%$ alcohol extract of pancreas) . . .......... Precipitated.

Lipase $(30 \%$ alcohol extract of pancreas $) . \ldots \ldots \ldots \ldots$. . Precipitated.

The incomplete removal of the amylase from saliva is peculiar in that the enzyme activity retained by the filtrate readily converts starch paste into soluble starch but further hydrolysis proceeds with difficulty or may not take place at all.

The enzymes studied, with one exception (amylase) are quantitatively removed from their solutions by aluminium hydroxide. The only zymogen studied was pepsinogen (prepared by extracting the mucous membrane of the stomach of pigs with $50 \%$ glycerol solution) which in $10 \%$ and in $25 \%$ glycerol solution is removed quantitatively only with the greatest difficulty.

1 This Journal, 35, 820 . 